\title{
The disclosure function of the U.S. patent system: evidence from the PTDL program and extreme snowfall
}

\section{Tim Martens ${ }^{1}$}

Accepted: 3 September 2021 / Published online: 28 October 2021

(C) The Author(s) 2021

\begin{abstract}
Are retail investors using uncurated disclosures in form of patents for their investment decisions? This study uses the investment decisions of retail investors and variation in the local availability of patent information to answer this question. The variation comes from changes in the locations of U.S. Patent and Trademark Depository Libraries over time. I find a strong increase in the local trading volume of stocks after the release of a patent in counties that have easier access to patent information. In addition, trades made by retail investors with easier access to this information yield higher returns, compared to trades made by other investors. These results indicate that disclosures of the U.S. Patent and Trademark Office facilitate the dissemination of patent information to retail investors. Furthermore, these results suggest that retail investors complement traditional curated disclosures with uncurated disclosures in form of patents.
\end{abstract}

Keywords Corporate disclosure · Information and knowledge · Innovation · Communication $\cdot$ Diffusion processes

JEL Classification M410 $\cdot \mathrm{G} 530 \cdot \mathrm{D} 830 \cdot \mathrm{O} 340 \cdot \mathrm{O} 330 \cdot \mathrm{G} 110$

Instead of concentrating on the metrics in financial statements, [Herbert] Wertheim is devoted to reading patents and spends two six-hour blocks each week poring over technical tomes. 'What's more important to me is, what is your intellectual capital to be able to grow?' Thanks to his engineering background, the technical nature of optometry and his experience as an inventor, the patent library is Wertheim's comfort zone. Stocks he invested in based on their impressive patent portfolios include IBM, 3M and Intel.

Forbes (2019)

Tim Martens

tim.martens@unibocconi.it

1 Bocconi University, Milan, Italy 


\section{Introduction}

Are retail investors using uncurated disclosures in form of patents for their investment decisions? While the literature examines retail investors' use of curated disclosures, such as financial statements, their use of uncurated disclosures remains largely unstudied. Whether retail investors use uncurated disclosures matters for regulators who aim to maintain equal access to public information. It also matters for managers, who may opt to use uncurated disclosures when communicating with investors. This study uses variation in the local availability of patent information and local investors' investment decisions to address how retail investors use patent disclosures.

Patents are uncurated disclosures published by the US Patent and Trademark Office (USPTO), and the information in them is not readily available from financial statements or other curated firm disclosures. However, patents are important in that they contain value-relevant information about the firm that is used by sophisticated market participants, such as institutional investors and financial analysts (e.g., Hirschey and Richardson 2004; Hochberg et al. 2018; Martens and Sextroh 2021).

Despite this value-relevance, it is unclear whether retail investors also use this information for their investment decisions. They face obstacles in doing so. The processing costs of patents, due to their technical nature, are higher than those of other sorts of information. On top of this, information that is harder to interpret is generally more likely to be ignored by less sophisticated investors (Bloomfield 2002). Hence retail investors may view patent information as too costly to be worth their time and effort (Blankespoor et al. 2019; Christensen et al. 2017; Hirshleifer and Teoh 2003; Huberman and Regev 2001; Merton 1987). As a consequence, they might not collect and use the information, despite its potential relevance for their investment decisions.

To examine whether retail investors do use patent information, I exploit features of the pre-Internet patent system in the United States from 1991 to 1996. In 1870, the USPTO started distributing copies of patent documents to libraries across the United States to broadly disseminate the information to the public. These Patent and Trademark Depository Libraries (PTDL) offer access to all resources necessary to conduct a full patent and trademark search. In 1977, the USPTO began to expand the PTDL program by designating at least one PTDL in every state. I use PTDL openings over time as a shock to the local availability of patent information.

To rule out that other determinants drive my results, I examine a second source of variation in local access to patent information that cannot plausibly relate to other determinants of trading: extreme snowfall, which inhibits access to the PTDL. During my sample period, local investors depended on physical access to the patent information. So I collect data on the daily weather in each county in my sample and identify snowfalls severe enough to disrupt or delay access to patent information. A large snowfall does not relate to either the USPTO's decision to open a PTDL or any other local characteristic affecting local trading volume, but it would have inhibited access to patent libraries.

I find that, all else equal, the existence of a PTDL increases the trading volume of local retail investors after the release of a patent by $4.6 \%$, the number of local 
trades by $0.4 \%$, and the probability of a local trade by $0.5 \%$. This positive association is stronger for high-value patent information, and it breaks down on extremely snowy days. Overall, these results strongly suggest that retail investors use patent information to inform their trading.

I also find that the retail investor reaction is stronger for firms with strong information environments and low trading costs but weaker on days with lower investor attention. These results suggest that retail investors use uncurated disclosures in form of patents to complement curated financial statements and analyst reports.

Finally, I show that the access to patent information increases the returns of trades made by retail investors between $0.7 \%$ and $7.9 \%$, compared to trades of other retail investors. This increase indicates that retail investors can understand the quality of the patents and use the information accordingly.

This study contributes to the literature examining the investment decisions of retail investors by documenting that they can collect and understand uncurated disclosures. Retail investors typically have fewer resources available for this sort of collection and analysis than do other stakeholders. As a result, any stakeholder with more resources can be inferred to likewise be able to use these uncurated disclosures (e.g., Glaeser 2018; Glaeser and Landsman 2020; Hegde et al. 2018; Kim and Valentine 2020; Saidi and Žaldokas 2020). Consequently, my results are relevant for regulators concerned with maintaining equal access to public information and who are charged with protecting retail investors. ${ }^{1}$

This study also contributes to the literature on the characteristics of alternative disclosures. By doing so, it addresses the call for research by Leuz and Wysocki (2016) to examine nontraditional disclosures. In this literature, few studies have examined the U.S. patent system (e.g., Glaeser and Landsman 2020; Glaeser et al. 2020). This study extends this literature by showing that firms can communicate with retail investors through the U.S. patent system.

The paper proceeds as follows. Section 2 describes the data and sample construction of this study. Section 3 contains the model and the results. Section 4 discusses of the generalizability of the results. Section 5 concludes.

\section{Data and sample construction}

I use the Patent and Trademark Depository Library program as a source of variation in the availability of patent information. Until 1870, patent documents were only located at the USPTO in Washington, D.C. In 1870, the USPTO started distributing copies of its documents to libraries across the United States for the sake of public dissemination. These Patent and Trademark Depository Libraries (PTDL) offer access to all resources necessary to conduct a full patent and trademark search. To ensure the efficient use of its resources, the USPTO targeted areas with large populations and with high patent and trademark activity (Sneed 2000). The information about the

\footnotetext{
${ }^{1}$ A former SEC chairperson, Mary Jo White, has highlighted that the SEC should focus on protecting retail investors: https://www.sec.gov/news/speech/mjw-speech-032114-protecting-retail-investor.
} 
selection process allows me to control for the selection mechanism of the USPTO and use the PTDL openings as a shock to local patent information. ${ }^{2}$

The standards governing the PTDL program allowed it to foster innovation via information transfers between inventors (Furman et al. 2020). Additionally, these standards continue to ensure that investors and financial analysts have access to patent information (USPTO 2003). For example, Brown and Arshem (1993) show that $6 \%$ of the PTDL visitors used the patent information for economic research, while $17 \%$ used it for legal, product, and market research.

The PTDL system also allows retail investors to use other patents to assess the value of individual patents or patent portfolios. For example, the citation patterns included in the patent document can be used to determine the value of the innovation (Fitzgerald et al. 2019). Therefore the opening of a PTDL is not identical to the simple disclosure of current patent information by firms or information intermediaries.

Since patents and trademarks are legal instruments and applying for either is a matter of law, the PTDL staff, as opposed to attorneys, are not allowed to provide any legal advice concerning patent issues. They can only explain the application process, show how to search for a patent or trademark, and answer questions about searching. They are not allowed to execute the patent or trademark search, submit or process a patent application, or give advice on patent searches or on applications. This restriction ensures that the PTDL program does not affect any other local characteristics directly. Hence I use the openings of PTDL across time to study direct information transfer between the USPTO and investors.

The primary data source of this study is the discount brokerage database of Barber and Odean (2000), which contains a local trading database and a local portfolio database with data from 1991 to 1996 . For my analysis, I use the local trading database, which contains the trades of almost 78,000 retail investors as well as their geographic and demographic information. I remove all accounts that do not have a valid zip code, which is needed to identify the investor locations. I aggregate the local trading database to the county-date level to calculate the local trading volume, which I use as the dependent variable. I include all counties that have shown any trading in firm $\mathrm{j}$ over the sample period as observations at time $\mathrm{t}$ in my sample. Hence county-date observations can have zero local trading volume.

I use the patent database of Kogan et al. (2017), which includes all patents filed with the USPTO from 1926 to 2010. I remove all observations that do not have information on the patents' technology class, citations, or economic value. The patent database has to be aggregated to the firm-date level, since a firm can receive several patents on the same date, which I refer to as the release of a patent. ${ }^{3}$

I merge the local-trading and patent databases with data from Compustat and Center for Research in Security Prices (CRSP). I supplement this data with the PTDL opening dates and locations from 1870 to 1996. The opening dates and locations are

\footnotetext{
${ }^{2}$ Please refer to Sneed (2000) for more information on the PTDL program.

${ }^{3}$ The release date/publication date and the grant date/issue date are identical over my sample period. Before the introduction of AIPA in 2000, patent information was only published at the grant date (Graham and Hegde 2015).
} 
collected from Oliver (2002). ${ }^{4}$ Table 2 shows the opening dates and locations of the PTDL in my sample.

I further supplement this data with population data from the Census State and County Intercensal database and snowfall data from the National Climatic Data Center GHCN-D database. The GHCN-D database contains weather data, including high and low temperatures, inches of snowfall, and precipitation. I calculate the average snowfall for all weather stations that are within a 10-mile radius of the counties in my sample. I add the number analyst earnings forecasts from the IBES summary database, the institutional ownership from the WRDS Thomson Reuters Institutional Holdings database, and M\&A news from the Capital IQ Key Developments database.

The sample consists of 1,472 unique firms that experience 39,419 unique patent events (release of a patent). It further consists of 1,378 unique counties that account for 4,470,927 unique observations. Limiting the sample period to 1991 to 1996 ensures robust inferences, since data after 1996 is subject to significant changes to institutions (e.g., American Inventors Protection Act) and technology (e.g., online databases). The sample period is largely pre-Internet, implying that investors must rely on the PTDL to access patent documents. ${ }^{5}$

\section{Methodology and estimation}

To examine the information transfer between the USPTO and retail investors, I estimate the following regression:

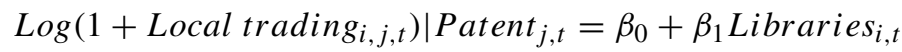

$$
\begin{aligned}
& +\sum \text { Controls }_{+}+\sum \text { County }_{i}+\sum \text { Firm }_{j} x \text { Date }_{t}
\end{aligned}
$$

where Local trading is the Local trading volume of retail investors in county $\mathrm{i}$ to firm j's release of a patent at time t. The variable is constructed over a three-day window; that is, patents are released on Tuesdays in my sample period and local trading volume accounts for trading from Tuesday to Thursday. All patents in my sample period are released on Tuesdays. Libraries represents an indicator variable that takes the value of one if there is a PTDL in county $i$ at time $t$ and zero otherwise. The coefficient on Libraries represents the trading volume after the release of a patent in counties with a PTDL, in contrast to those without one. I assume that investors who receive the patent information react similarly to the release of a patent across locations, since the information is identical in all locations. In other words,

\footnotetext{
${ }^{4}$ I adjust the opening date of the New Haven Free Public Library to August 11, 1986, since it replaced the Science Park Library, which opened at that date.

${ }^{5}$ The PTDL system was not the only source of patent information for investors. The USPTO started the AIDS online database, which contained AIDS-related patent information, on December 1, 1994, and the PatBib online database, which contained patent information from 1986 to 1995, on November 9, 1995. However, the PatBib database started to include the latest patents only on February 1, 1996. Furthermore, the sample period is not entirely pre-Internet. Barber and Odean (2002) show that 1,607 households in the local trading database switched from phone-based to Internet-based trading in the course of the sample period.
} 
investors in Santa Clara County and New York County would react similarly. I also assume investors near Boston are more likely to use the resources at the Boston Public Library than those at other libraries. This assumption comports with the findings of Brown and Arshem (1993), who show that most visitors originate from the area near the PTDL. In addition, the setting requires that only a subset of local investors use the PTDL. These investors then disseminate their information, ensuring local transfer (Ivković and Weisbenner 2007; Hong et al. 2005).

I include four county characteristics to control for the decision to open a PTDL in a county. (1) I include $\log (1+$ County patents $)$, which is defined as the natural logarithm of one plus the the number of patents in thousands released in county in the year of the event date. (2) I include $\log (1+$ County scientific value $)$, which is defined as the natural logarithm of one plus the adjusted number of citations in thousands of patents released in county i in the year of the event date. (3) I include $\log (1+$ County economic value $)$, which is defined as the natural logarithm of one plus the economic value in billions of patents released in county $i$ in the year of the event date. (4) I include $\log$ (County population), which is defined as the natural logarithm of the population in thousands in county $\mathrm{i}$ in the year of the event date. I also include Local firm, which is an indicator variable that takes the value of one if the headquarters of firm $\mathrm{j}$ is located in county $\mathrm{i}$ and zero otherwise. Please refer to Appendix A for descriptions of all variables.

I include county fixed effects to control for county time-invariant characteristics (e.g., larger counties might cause stronger reactions than smaller ones). I include firm $x$ date fixed effects to control for all fundamentals of the event (e.g., the scientific and economic value of the patent) and any simultaneous actions (e.g., positive or negative media coverage). By clustering residuals by county, I compute standard errors that allow each county to have its own unobserved effect on trading volume (Petersen 2009).

\subsection{Descriptive statistics}

Table 3 reports the descriptive statistics for the variables in this analysis. 867,034 (19.4\%) observations are in counties with a PTDL, while 3,603,893 (80.6\%) are in counties without one. In other words, for each observation with a PTDL, I observe on average four observations without one, which allows me to vary the patent information availability for different groups of investors for the same patent release. The mean of the Local trading volume is substantially higher in counties with a PTDL than in counties without one (\$550.25 versus $\$ 205.07$ ). Furthermore, counties with a PTDL have on average a larger population and generate more patents. These patents have higher scientific and economic values.

\subsection{PTDL and local trading volume}

In Table 4, I examine the association between patent information availability and local trading volume. In columns (1) to (3), I show the estimates of Eq. 1 with 
the natural logarithm of one plus the absolute dollar trading volume in firm j's stock in county $i$ within three days of the patent release as the dependent variable. Column (1) considers only the treatment variable Libraries and standard errors clustered by county. The result of column (1) suggests that investors in counties with a PTDL increase their local trading volume by $12.9 \%$, in contrast to investors in counties without a PTDL. To ensure that these results are not driven by the USPTO selection mechanism, I include the variables $\log (1+$ County patents $), \log (1+$ County scientific value $), \log (1+$ County economic value $)$, and Log (County population) as control variables in column (2) (Sneed 2000). These variables mimic the USPTO selection mechanism and ensure an unbiased coefficient estimate for the treatment variable Libraries. Furthermore, to ensure that the results are not driven by any simultaneous action that materializes in counties with a PTDL, due to the location choice of firms, I include the variable Local firm. Firms might select counties with a PTDL as a location for their headquarters to benefit from resources at the library. If any simultaneous action is correlated with the firm's location choice, the coefficient estimate for the treatment variable Libraries would be biased. The variable also accounts for any home bias that might affect local trading (Ivković and Weisbenner 2005; Seasholes and Zhu 2010). And column (2) includes county fixed effects to control for county time-invariant characteristics. The results of column (2) indicate that the existence of a PTDL increases local trading volume by $5.5 \%$, versus counties without a PTDL. However, this specification ignores that some events might be associated with higher trading volumes for reasons unrelated to the PTDL. Hence, to control for these factors, column (3) adds firm $\mathrm{x}$ date fixed effects to the model. The inclusion of these fixed effects decreases the coefficient estimates for Libraries to $4.6 \%$. The coefficient estimates for Libraries for these specifications are positive and significant at the $p \leq 0.1$ level. The adjusted $R^{2}$ increases from $0.2 \%$ in column (1) to $3.7 \%$ in column (3), highlighting the importance of these characteristics in this analysis.

To ensure that the results are not driven by outliers, columns (4) and (5) present the coefficient estimates for Libraries for two alternative dependent variables that treat each observation equally. Column (4) uses the natural logarithm of one plus the number of trades in firm j's stock in county i within three days of patent release. Column (5) uses a local trading indicator variable that takes the value one if there was trading in firm j's stock in county i within three days of patent release and zero otherwise. I use a linear probability model to account for the many fixed effects in this analysis. Both dependent variables minimize the influence of large or small trades on the estimation. The existence of a PTDL increases the number of local trades by $0.4 \%$ and the probability of a local trade by $0.5 \%$. In addition, the coefficient estimates for the treatment variable Libraries are significant at the $p \leq 0.1$ level, indicating the results of the baseline specification are not driven by outliers.

The level of significance is due to the fact that the coefficient estimates represent the average effect across low-value and high-value patents. However, the retail investor reaction is driven by the value of the patent information and not by the PTDL itself. In Table 5, I show greater significance, due to the interaction with the scientific value in the analysis. 
A frequently stated concern with difference-in-difference research designs is the violation of the parallel trends assumption. To address this concern, I define leads $(t-4$ to $t-2)$ and lags $(t=0$ to $t+2)$ of the treatment variable Libraries as halfyear increments and use them as treatment variables. ${ }^{6}$ For example, Libraries $t-2$ represents an indicator variable that takes the value of one a year before the opening of a PTDL and zero otherwise. Similarly, Libraries $t+2$ is an indicator variable that takes the value of one a year after the opening of a PTDL and zero otherwise. The baseline period in this analysis is the period $t-1$. In Fig. 1, I examine the coefficient estimates before and after the opening of a PTDL to provide evidence of the validity of the parallel trends assumption. The coefficient estimates for the leads of the treatment variables Libraries are not statistically significant at the $p \leq 0.1$ level, highlighting that there are no systematic differences in local trading volume between both groups of counties before the opening of a PTDL.

The analysis only considers short-term market reactions after the release of a patent to ensure a clean identification of the information transfer. As a result, the size of the coefficient estimates for Libraries is not equivalent to the total economic effect of the information transfer. In fact, the results of this analysis likely constitute only a fraction of the total economic effect, since patent information is also used in licensing agreements and debt contracts, which might be affected by the information transfer (Mann 2018). In addition, these information transfers might influence the efficiency of stock price discovery (Hegde et al. 2018). In sum, the results of my analysis underline the existence of an information transfer between the USPTO and retail investors. These results also highlight that retail investors collect patent information and use it in their investment decisions.

\subsection{Pre-release local trading volume, scientific value, and snow}

To ensure that the results of the previous analysis are not driven by factors unrelated to an information transfer between the USPTO and retail investors, I examine the financial market reaction before the release of a patent. The specification of the previous analysis would be questionable if the existence of a PTDL were associated with the retail investor reaction before the release of a patent. The dependent variables in columns (1) and (2) of Table 5 are considered on days $-3,-2$, and -1 before the patent release date. The coefficient estimates for Libraries are not statistically significant at the $p \leq 0.1$ level for both specifications, suggesting that any increase in the local trading volume in the previous analysis is not driven by any factors unrelated to the release of a patent and hence unrelated to the information transfer.

In addition, if the results of the previous analysis are driven by an information transfer between the USPTO and retail investors, I expect the value of the information to drive the retail investor reaction. Consequently, columns (3) and (4) of Table 5 show the coefficient estimates for the treatment variable Libraries and its

\footnotetext{
${ }^{6}$ I also include the lead $t<-4$ and the lag $t>2$, which are not shown in the graph since they have no meaningful interpretation.
} 
interaction with the scientific value $\log (1+$ Scientific value $)$. I define $\log (1+$ Scientific value) the natural logarithm of one plus the number of citations of the patent event. I follow prior research and deduct from the citation count the mean number of citations for all patents in the same technology class in the same year. This adjustment accounts for systematic differences between patents in different technology classes in different years (Hall et al. 2001). To ensure nonnegative values, I set the adjusted citations to zero for patents that have adjusted citations below zero. $^{7}$ The coefficient estimates for Libraries are not statistically significant at the $p \leq 0.1$ level; however, the coefficient estimates for the interaction are significant at the $p \leq 0.01$ level for both specifications. The result of column (3) indicates that a $1 \%$ increase in the scientific value of a patent increases the local trading volume by $3.1 \%$ if a PTDL exists in county $i$ at time $t$. A similar association is observable in column (4) for the number of local trades. These results suggest that the investors are not reacting to the opening of a PTDL; they are reacting to the release of a patent and the value of the information.

To rule out that the results of the previous analysis are driven by the USPTO selection mechanism, I follow the approach of Engelberg and Parsons (2011) and use extreme snowfall as a exogenous shock to patent information availability. I exploit the fact that the sample period is largely pre-Internet and investors must physically access patent information if they want to use it. Extreme snowfall is unrelated to the USPTO selection mechanism; however, it can prevent patent information from reaching investors by, for example, blocking roads. Columns (5) to (6) of Table 5 include the coefficient estimates for the variable Snow and its interaction with the treatment variable Libraries. The variable is an indicator variable that takes the value of one if the snowfall in county $i$ within three days after patent release exceeds 20 inches and zero otherwise.

In this setting, the coefficient estimates for Libraries represent the effect of a PTDL on local trading volume on days without extreme snowfall. The inclusion of the interaction of Libraries and Snow does not substantially change the coefficient estimate for the treatment variable Libraries, compared to the baseline regression. Furthermore, the lack of statistical significance of the coefficient estimate for Snow indicates that extreme snowfall itself does not influence local trading volume significantly. The variable of interest is the interaction of Libraries and Snow, which is negative and significant at the $p \leq 0.05$ level. These coefficient estimates indicate that information transfer breaks down on days with extreme snowfall, suggesting the existence of a transfer between the USPTO and retail investors. It is noteworthy that the interaction variable offsets the positive effect of the PTDL (i.e., the sum of these coefficients is not statistically different from zero at the $p \leq 0.1$ level), which means that the information transfer is severely disrupted. ${ }^{8}$ Overall, these results ensure that the results of the previous analysis are not driven by the USPTO selection mechanism but by an information transfer between the USPTO and retail investors.

\footnotetext{
${ }^{7}$ The economic value of the patent, measured through the aggregate market reaction, cannot be included as a control variable because the aggregate market reaction is mechanically affected by the local market reaction and hence would introduce endogeneity into the model.

${ }^{8}$ The results are not sensitive to various alternative definitions of the variable Snow (e.g., 22 inches).
} 


\subsection{Characteristics of the information transfer}

In Table 6, I examine the characteristics of the information transfer. In columns (1) to (5), I use the market reactions on the individual days after the release of a patent to measure the speed of the transfer. The coefficient estimates indicate that the transfer is relatively fast, since the strongest market reactions occur on day 0 (release date) and day 1 after the release ( $p \leq 0.1)$. The existence of a PTDL increases local trading volume by $1.6 \%$ on day 0 and by $2.5 \%$ on day 1 . Market reactions from day 2 to day 4 are weaker, suggesting that the retail investors incorporate the patent information quickly into the stock price. This finding comports with the results of Kogan et al. (2017), who demonstrate that the strongest aggregate financial market reactions occur from day 0 to day 2 . The speed of the market reactions also mitigates the concern that the results of the previous analysis are driven by local news coverage, since this would require patent information to be disseminated on release day, which is unlikely, given the existence of print deadlines.

The literature has shown that distance is an important determinant of information transfers (e.g., Belenzon and Schankerman 2013; Agrawal et al. 2017). I follow this literature and examine how distance affects the information transfer in my setting. In column (6) of Table 6, I include the variable $\log$ (Distance), which is defined as the natural logarithm of the distance of investors in county $i$ to the closest PTDL at time $\mathrm{t}$ in miles. ${ }^{9}$ The coefficient estimates for $\log$ (Distance) are negative and statistically significant at the $p \leq 0.05$ level. The result in column (6) indicates that a $1 \%$ increase in the distance to the closest PTDL decreases the local trading volume by $1.3 \%$, suggesting that distance does affect the information transfer significantly. A possible explanation for this result is that the patent information needs time to reach investors farther from the PTDL.

\subsection{Investor characteristics}

In Table 7, I focus on the characteristics of different groups of retail investors. The results of this analysis should be viewed as descriptive and interpreted with caution. They do not rule out alternative explanations, and a large share of observations lack necessary data.

In columns (1) to (4), I examine whether investors with different jobs differ in their sensitivity to the availability of patent information. Columns (1) and (2) include the coefficient estimates for Libraries for investors in management jobs and technical jobs, respectively. Both coefficient estimates are not statistically significant

\footnotetext{
${ }^{9}$ The distance to the closest PTDL is strictly larger than zero because the measure is based on PTDL zip codes, which differ from county zip codes. Hence even investors in a county with a PTDL exhibit a very small but positive distance.
} 
at the $p \leq 0.1$ level. Columns (3) and (4) include the coefficient estimates for Libraries for retired investors and the remaining investors, respectively. The coefficient estimate for the retired investors is significant at the $p \leq 0.01$ level, while it is not statistically significant at the $p \leq 0.1$ level for the remaining investors. A possible explanation for these results is that retail investors have sufficient knowledge to process patent information, independent of their jobs, but that collecting and understanding patent information requires adequate time. However, the insignificant coefficient estimates should be interpreted with caution, as they are marginally significant and might be the result of a lack of statistical power.

In columns (5) and (6), I examine whether females and males differ in their use of patent information. The coefficient estimate for Libraries for female investors is not statistically significant at the $p \leq 0.01$ level, while it is at the $p \leq 0.05$ level for male investors. A possible explanation for the difference is differing levels of confidence in the precision of the information (Barber and Odean 2001).

\subsection{Information environment, trading costs, and attention}

In columns (1) and (2) of Table 8, I examine whether the information environment affects the retail investors and their use of patent information. I measure the information environment using two variables that are positively associated with a strong information environment: analyst following and institutional ownership (Bhushan 1989; Bushee and Noe 2000; Shores 1990). I define Log $(1+$ Analyst following $)$ as the natural logarithm of one plus the number of analyst earnings forecasts for firm $\mathrm{i}$ before the release of the patent. I define Institutional ownership as the percentage of firms j's shares held by institutional investors before the release of the patent. I expect that retail investors react more strongly when the information environment is stronger and hence search costs are lower. Columns (1) and (2) include the coefficient estimates for the interactions of Libraries with $\log (1+$ Analyst following $)$ and Institutional ownership, respectively. Both coefficients are positive and statistically significant at the $p \leq 0.01$ level, consistent with the argument that retail investors complement traditional curated disclosures, such as financial statements and analyst reports, with uncurated patent disclosures.

In columns (3) and (4), I examine whether trading costs affect the retail investors. I am using two measures of liquidity that are associated with trading costs: turnover and bid-ask spread. I define Turnover as the ratio of daily volume and shares outstanding the day before the release of the patent. Similarly, I define Bid - ask spread as the bid-ask spread the day before the release of the patent. The bid-ask spread is calculated using the Corwin and Schultz (2012) estimator. I expect that retail investors react more strongly to patent information when liquidity is high and trading costs are low. Columns (3) and (4) include the coefficient estimates for the interactions of Libraries with Turnover and Bid-ask spread, respectively. Both coefficients are statistically significant at the $p \leq 0.05$ level, consistent with the argument that low trading costs make trades more attractive for retail investors. 
Finally, in columns (5) and (6), I examine whether the intensity of attention affects retail investors and their use of patent information. I use the amount of competing information and a salient corporate event as proxies for attention. I define $\log$ (Daily patents) as the natural logarithm of the number of patents released on day t. I define $M \& A$ news as an indicator variable that takes the value of one if there is any M\&A news within the seven days before time $t$ and zero otherwise. Since stocks in the news grab the attention of retail investors, I expect these investors will react more to patent information if there is less information competing for their attention and if there is M\&A news, increasing attention on the pertinent firm (Barber and Odean 2008). Columns (5) and (6) include the coefficient estimates for the interactions of Libraries with $\log ($ Daily patents) and $M \& A$ news, respectively. The negative coefficient $\log$ (Daily patents) $(p \leq 0.05)$ and the positive coefficient on $M \& A$ news $(p \leq 0.01)$ are consistent with argument that attention influences the response of retail investors.

\subsection{PTDL and profitability}

In Table 9, I examine whether trades made by retail investors with access to patent documents are more profitable than those made by retail investors without access. I use a sample of individual trading days with buying activity, which allows me to accurately calculate the returns. I calculate the cumulative abnormal returns (CAR) and buy-and-hold abnormal returns (BHAR) for 20, 60, and 240 trading days. I use a market-adjusted model, which uses abnormal returns, defined as returns in excess of the CRSP value-weighted market return, to calculate the abnormal returns. I estimate a regression with the CAR and BHAR as dependent variables to determine the influence of patent information on profitability. Columns (1) to (6) include coefficient estimates for Libraries across event windows. The coefficient on Libraries represents the difference in returns for trades made by retail investors in counties with a PTDL, compared to trades made by retail investors in counties without a PTDL. The coefficient estimates for Libraries are significant at the $p \leq 0.05$ level across all specifications. The return differentials range from $0.7 \%$ to $7.9 \%$, depending on the model and the event window. These return differentials translate into returns of 115 and 1,293 dollars, respectively. This result suggests that retail investors collect and use patent information, since availability of this information is associated with significantly higher stock returns.

\section{Discussion}

To understand the generalizability of my results, it is necessary to answer the question whether these results transfer to the present. While the introduction of the Internet has made the PTDL program obsolete, the features of my setting still allow a discussion of generalizability. 
The PTDL program as a disclosure channel is straightforward: it only offers access to patent information, and the information itself is not affected by the PTDL program. Hence any other disclosure channel that would offer access to current and historical patent documents to retail investors would most likely affect retail investors in a similar way. In addition, the format of patent documents did not change significantly over time. This simplicity and consistency suggest that today retail investors can collect and use patent information provided through other channels.

While investors today are confronted with a large body of information, it is unclear whether information overload has worsened over time, since firms try to address the issue by adjusting their disclosures (e.g., Chapman et al. 2019; EY 2014). Today retail investors have many tools to facilitate their collection and analysis of patent information (e.g., Google Patents and PatentsView). They also have many means of sharing information with each others (e.g., social media such as Reddit and Twitter). Furthermore, individual retail investors share their information with other retail investors (Ivković and Weisbenner 2007; Shiller and Pound 1989). Similarly, the transfer of technological information is strongly geographically localized (Belenzon and Schankerman 2013; Jaffe et al. 1993). These features suggest that the results of this study do transfer to today.

In addition, if retail investors can understand patent information, institutional investors, which are generally considered more sophisticated, should also be able to (Ayers et al. 2011). This conclusion is consistent with the growing stream of literature that highlights the value of patent information for investors (e.g., Hirshleifer et al. 2013, 2018; Hochberg et al. 2018).

\section{Conclusion}

This study uses the investment decisions of retail investors and variation in the local availability of patent information to determine whether retail investors use uncurated disclosures in form of patents. I document a positive association between the local availability of patent information and local trading volume after the release of a patent. All else equal, the existence of a PTDL increases the trading volume of local retail investors after the release of a patent by $4.6 \%$, the number of local trades by $0.4 \%$, and the probability of a local trade by $0.5 \%$. The effect is stronger for high value information and for investors closer to the patent libraries. This association breaks down on days with extreme snowfall, indicating an information transfer between the USPTO and retail investors. Furthermore, I show that the response of retail investors is stronger for firms with strong information environments and low trading costs but weaker on days with lower investor attention. Finally, I show that the existence of a PTDL increases the return of trades made by retail investors between 0.7 and $7.9 \%$. These results indicate that the disclosures of the USPTO facilitate the dissemination of patent information to retail investors. Furthermore, these results suggest that retail investors complement curated disclosures with uncurated ones in form of patents. 


\section{Appendix A: Variable descriptions}

Table 1 Variable definitions

Trading-related variables

Log $(1+$ Local trading volume

Log $1+$ Number of local trades

Local trading indicator

Log $1+$ Local management trading volume

Log(1+Local technical trading volume

Log $(1+$ Local retiredtrading volume

Log $(1+$ Local other trading volume
The natural logarithm of one plus the local dollar trading volume of retail investors in county i to firm j's release of a patent at time t. The variable is constructed over a three day window; i.e., patents are released on Tuesdays in my sample period, and local trading volume accounts for trading volume from Tuesday to Thursday.

The natural logarithm of one plus the number of trades of retail investors in county i to firm j's release of a patent at time t. The variable is constructed over a three day window; i.e., patents are released on Tuesdays in my sample period, and number of local trades accounts for trades from Tuesday to Thursday.

An indicator variable that takes the value one if there was trading in firm j's stock in county i to firm j's release of a patent at time $t$ and zero otherwise. The variable is constructed over a three day window; i.e., patents are released on Tuesdays in my sample period, and the local trading indicator accounts for trading activity from Tuesday to Thursday.

The natural logarithm of one plus the local dollar trading volume of retail investors in management jobs in county $i$ to firm j's release of a patent at time t. The variable is constructed over a three day window; i.e., patents are released on Tuesdays in my sample period, and local trading volume accounts for trading volume from Tuesday to Thursday.

The natural logarithm of one plus the local dollar trading volume of retail investors in technical jobs in county $i$ to firm j's release of a patent at time t. The variable is constructed over a three day window; i.e., patents are released on Tuesdays in my sample period, and local trading volume accounts for trading volume from Tuesday to Thursday.

The natural logarithm of one plus the local dollar trading volume of retired retail investors in county i to firm j's release of a patent at time t. The variable is constructed over a three day window; i.e., patents are released on Tuesdays in my sample period, and local trading volume accounts for trading volume from Tuesday to Thursday.

The natural logarithm of one plus the local dollar trading volume of retail investors who are not in management jobs or in technical jobs and who are not retired in county $\mathrm{i}$ to firm j's release of a patent at time t. The variable is constructed over a three day window; i.e., patents are released on Tuesdays in my sample period, and local trading volume accounts for trading volume from Tuesday to Thursday. 
Table 1 (continued)

\section{CAR}

BHAR

County-specific variables

\author{
Libraries \\ $\log (1+$ County patents $)$ \\ $\log (1+$ County scientific value $)$
}

$\log (1+$ County economic value $)$

Log(County population)

Log(Distance)

Snow
The cumulative abnormal return over the event window to firm j's release of a patent at time t. The cumulative abnormal return is calculated using a market-adjusted model that uses abnormal returns defined in excess of the CRSP value-weighted market return assuming a market beta of 1.

The buy-and-hold abnormal return over the event window to firm j's release of a patent at time t. The buy-and-hold abnormal return is calculated using a market-adjusted model that uses abnormal returns defined in excess of the CRSP value- weighted market return assuming a market beta of 1 .

An indicator variable that takes the value of one if there is a PTDL in county $i$ at time $t$ and zero otherwise.

The natural logarithm of one plus the the number of patents in thousands released in county $i$ in the year of the event date $\mathrm{i}$.

The natural logarithm of one plus the adjusted number of citations in thousands of patents released in county i in the year of the event date. The mean number of citations for all patents in the same technology class in the same year is deducted from the citation count. The adjusted citations are set to zero for patents that have adjusted citations below zero to ensure nonnegative values.

The natural logarithm of one plus the economic value in millions of patents released in county $i$ in the year of the event date. The adjusted economic value is the estimated economic value from Kogan et al. (2017) adjusted by the mean economic value for all patents in the same technology class in the same year.

The natural logarithm of the population in thousands in county $i$ in the year of the event date.

The natural logarithm of the distance of investors in county $i$ to the closest PTDL at time $t$ in miles.

An indicator variable that takes the value of one if the snowfall in county $i$ within three days after patent release exceeds 20 inches and zero otherwise.

Firm-specific and patent event-specific variables

$\log (1+$ Scientific value $)$
The natural logarithm of one plus the adjusted number of citations of the patent event. The mean number of citations for all patents in the same technology class in the same year is deducted from the citation count. The adjusted citations are set to zero for patents that have adjusted citations below zero to ensure nonnegative values. 
Table 1 (continued)

\begin{tabular}{ll}
\hline Local firm & $\begin{array}{l}\text { An indicator variable that takes the value of one if the } \\
\text { headquarters of firm } \mathrm{j} \text { is located in county i and zero } \\
\text { otherwise. }\end{array}$ \\
The natural logarithm of one plus the number of ana- \\
lyst earnings forecasts for firm i before the release of the \\
patent. \\
as the percentage of stocks held by institutional investors \\
before the release of the patent. \\
The ratio of daily volume and shares outstanding the day \\
before the release of the patent. \\
The bid ask spread the day before the release of the patent. \\
The bid ask spread is calculated using the Corwin and \\
Schultz (2012) estimator. \\
The natural logarithm of the number of patents released on day t. \\
Thead \\
An indicator variable that takes the value of one if there is \\
any M\&A news within the seven days prior to time t and \\
zero otherwise.
\end{tabular}




\section{Appendix B: Results}

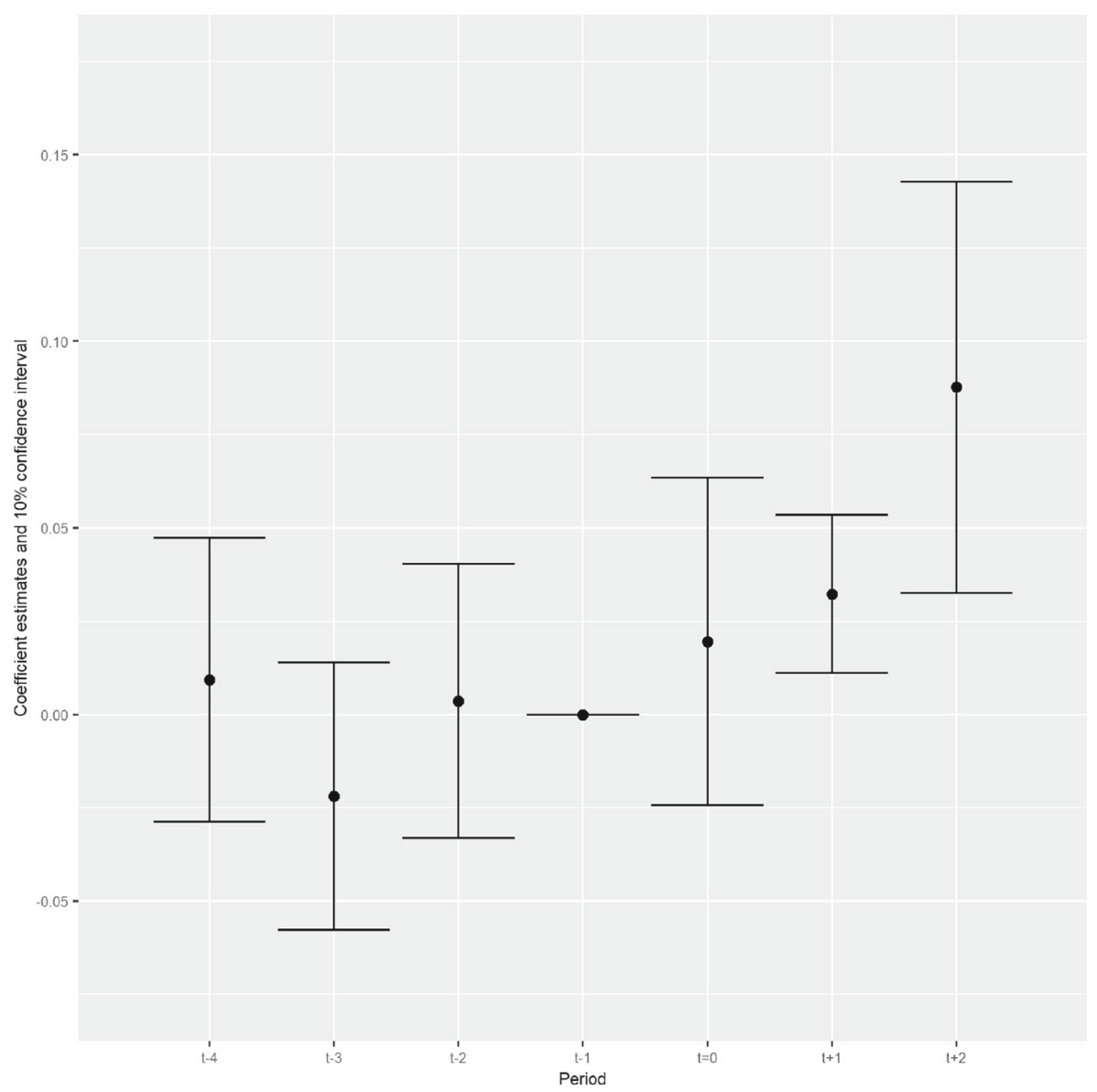

Fig. 1 Regression results: dynamic specification. Notes: The graph shows the coefficient estimates and $10 \%$ confidence intervals for the treatment variable before and after the opening of a PTDL. The leads and lags are defined as half years increments, relative to the opening of a PTDL. Standard errors are clustered by county. Please refer to Appendix A for descriptions of all variables 
Table 2 PTDL locations and designation dates

\begin{tabular}{|c|c|c|c|}
\hline State & County & City & Designation date \\
\hline MA & Suffolk County & Boston & 1870 \\
\hline NY & New York County & New York & 1870 \\
\hline NY & Albany County & Albany & 1870 \\
\hline $\mathrm{OH}$ & Franklin County & Columbus & 1870 \\
\hline MO & St. Louis City & St. Louis & 1870 \\
\hline $\mathrm{CA}$ & Los Angeles County & Los Angeles & 1870 \\
\hline NY & Erie County & Buffalo & 1871 \\
\hline $\mathrm{OH}$ & Hamilton County & Cincinnati & 1871 \\
\hline MI & Wayne County & Detroit & 1871 \\
\hline IL & Cook County & Chicago & 1876 \\
\hline NJ & Essex County & Newark & 1880 \\
\hline $\mathrm{OH}$ & Cuyahoga County & Cleveland & 1890 \\
\hline RI & Providence County & Providence & 1901 \\
\hline PA & Allegheny County & Pittsburgh & 1902 \\
\hline $\mathrm{OH}$ & Lucas County & Toledo & 1934 \\
\hline GA & Fulton County & Atlanta & 1946 \\
\hline MO & Jackson County & Kansas City & 1946 \\
\hline WI & Milwaukee County & Milwaukee & 1949 \\
\hline $\mathrm{OK}$ & Payne County & Stillwater & 1956 \\
\hline $\mathrm{CA}$ & Santa Clara County & Sunnyvale & 1963 \\
\hline WI & Dane County & Madison & 1976-04-26 \\
\hline $\mathrm{TX}$ & Harris County & Houston & $1977-07-28$ \\
\hline $\mathrm{AL}$ & Jefferson County & Birmingham & 1977-08-08 \\
\hline WA & King County & Seattle & 1977-08-08 \\
\hline $\mathrm{NC}$ & Wake County & Raleigh & $1977-09-26$ \\
\hline $\mathrm{CO}$ & Denver County & Denver & 1977-11-11 \\
\hline $\mathrm{TX}$ & Dallas County & Dallas & $1977-11-30$ \\
\hline $\mathrm{NE}$ & Lancaster County & Lincoln & 1978-01-05 \\
\hline $\mathrm{TN}$ & Shelby County & Memphis & 1979-01-18 \\
\hline CA & Sacramento County & Sacramento & 1979-04-13 \\
\hline $\mathrm{PA}$ & Centre County & University Park & 1979-04-23 \\
\hline $\mathrm{MN}$ & Hennepin County & Minneapolis & 1980-09-12 \\
\hline $\mathrm{DE}$ & New Castle County & Newark & $1980-11-26$ \\
\hline $\mathrm{AZ}$ & Maricopa County & Tempe & 1981-06-15 \\
\hline LA & East Baton Rouge Parish & Baton Rouge & 1981-06-24 \\
\hline NV & Washoe County & Reno & $1983-05-16$ \\
\hline $\mathrm{TX}$ & Travis County & Austin & 1983-06-16 \\
\hline IN & Marion County & Indianapolis & 1983-09-07 \\
\hline AL & Lee County & Auburn & $1983-10-13$ \\
\hline ID & Latah County & Moscow & 1983-11-03 \\
\hline
\end{tabular}


Table 2 (continued)

\begin{tabular}{|c|c|c|c|}
\hline State & County & City & Designation date \\
\hline NM & Bernalillo County & Albuquerque & 1983-11-03 \\
\hline MI & Washtenaw County & Ann Arbor & 1983-11-04 \\
\hline $\mathrm{TX}$ & Brazos County & College Station & $1983-12-22$ \\
\hline IL & Sangamon County & Springfield & 1984-01-17 \\
\hline MD & Prince George's County & College Park & $1984-01-25$ \\
\hline $\mathrm{CA}$ & San Diego County & San Diego & $1984-01-26$ \\
\hline MT & Silver Bow County & Butte & 1984-03-01 \\
\hline UT & Salt Lake County & Salt Lake City & 1984-04-06 \\
\hline FL & Miami-Dade County & Miami & $1984-07-25$ \\
\hline FL & Broward County & Fort Lauderdale & 1984-11-01 \\
\hline MA & Hampshire County & Amherst & $1984-11-14$ \\
\hline $\mathrm{AK}$ & Anchorage Municipality & Anchorage & 1984-12-04 \\
\hline AR & Pulaski County & Little Rock & $1985-01-18$ \\
\hline $\mathrm{TN}$ & Davidson County & Nashville & $1985-07-26$ \\
\hline VA & Richmond city & Richmond & $1985-09-26$ \\
\hline PA & Philadelphia County & Philadelphia & $1986-05-05$ \\
\hline $\mathrm{CT}$ & New Haven County & New Haven & 1986-08-11 \\
\hline $\mathrm{DC}$ & District of Columbia & Washington & 1986-12-08 \\
\hline KY & Jefferson County & Louisville & $1988-03-28$ \\
\hline IA & Polk County & Des Moines & 1988-12-09 \\
\hline FL & Orange County & Orlando & $1988-12-30$ \\
\hline NJ & Middlesex County & Piscataway & 1989-05-09 \\
\hline $\mathrm{HI}$ & Honolulu County & Honolulu & $1989-12-18$ \\
\hline ND & Grand Forks County & Grand Forks & $1990-01-26$ \\
\hline FL & Hillsborough County & Tampa & $1990-03-20$ \\
\hline MS & Hinds County & Jackson & 1990-06-19 \\
\hline KS & Sedgwick County & Wichita & 1991-01-31 \\
\hline IN & Tippecanoe County & West Lafayette & 1991-08-09 \\
\hline MI & Mecosta County & Big Rapids & $1991-08-22$ \\
\hline WV & Monongalia County & Morgantown & 1991-12-02 \\
\hline $\mathrm{SC}$ & Pickens County & Clemson & 1992-06-03 \\
\hline ME & Penobscot County & Orono & $1993-12-23$ \\
\hline $\mathrm{CA}$ & San Francisco County & San Francisco & 1994-01-19 \\
\hline SD & Pennington County & Rapid City & $1994-02-10$ \\
\hline PR & Mayaguez Municipio & Mayaguez & $1995-03-10$ \\
\hline OR & Multnomah County & Portland & $1995-07-27$ \\
\hline $\mathrm{OH}$ & Summit County & Akron & $1995-09-18$ \\
\hline $\mathrm{TX}$ & Lubbock County & Lubbock & $1995-10-31$ \\
\hline NH & Merrimack County & Concord & $1996-02-21$ \\
\hline
\end{tabular}




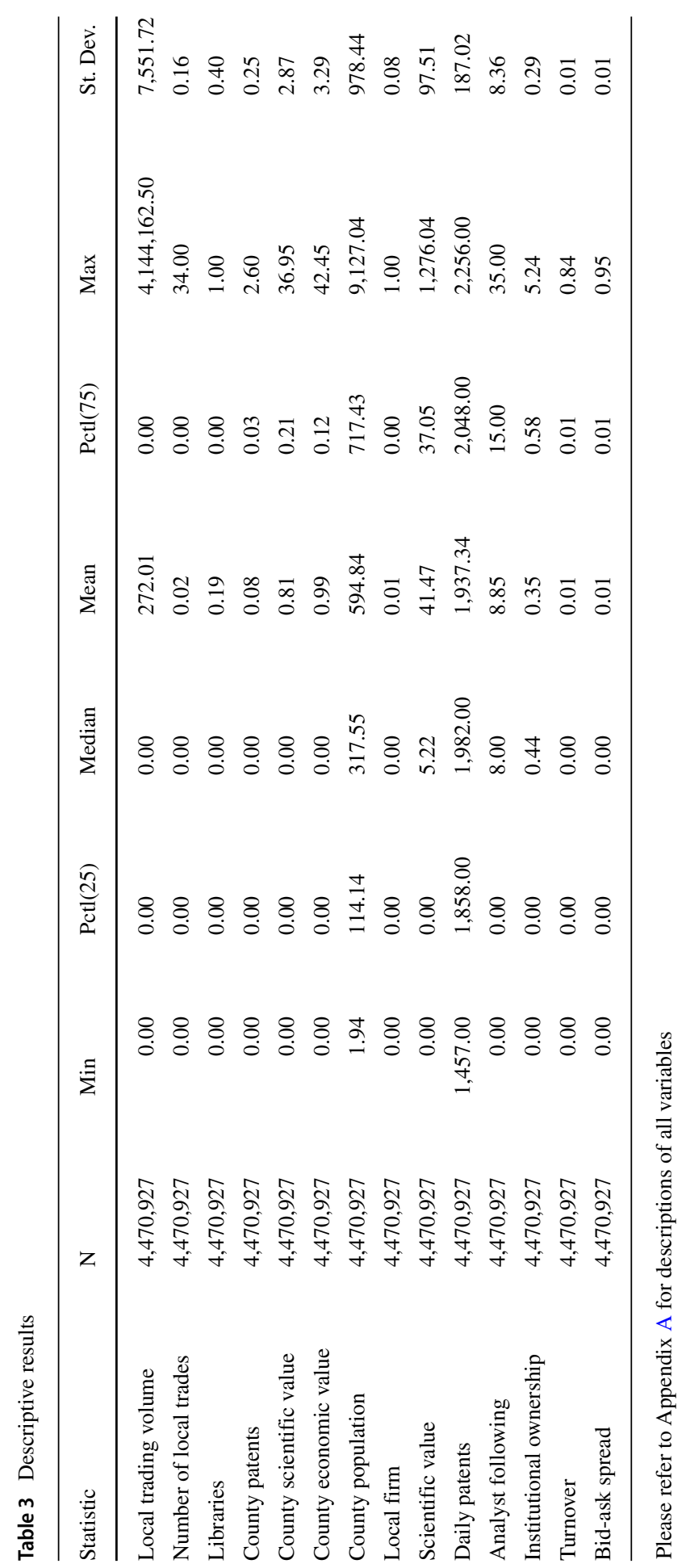


Table 4 Regression results: PTDL and local trading volume

\begin{tabular}{|c|c|c|c|c|c|}
\hline & \multicolumn{3}{|c|}{$\begin{array}{l}\log (1+\text { Local trading volume }) \\
\text { (Post-release) }\end{array}$} & \multirow{2}{*}{$\begin{array}{l}\log (1+ \\
\text { Number of } \\
\text { local trades) } \\
\text { (Post-rel.) } \\
\text { (4) }\end{array}$} & \multirow{2}{*}{$\begin{array}{l}\text { Local } \\
\text { trading } \\
\text { indicator } \\
\text { (Post-rel.) } \\
(5)\end{array}$} \\
\hline & (1) & (2) & (3) & & \\
\hline Libraries & $\begin{array}{l}0.121^{* * *} \\
(3.583)\end{array}$ & $\begin{array}{l}0.054^{* * *} \\
(2.778)\end{array}$ & $\begin{array}{l}0.045^{*} \\
(1.688)\end{array}$ & $\begin{array}{l}0.004^{*} \\
(1.792)\end{array}$ & $\begin{array}{l}0.005^{*} \\
(1.950)\end{array}$ \\
\hline \multicolumn{6}{|l|}{ Control variables } \\
\hline $\log (1+$ County patents $)$ & & $\begin{array}{l}0.101 \\
(0.794)\end{array}$ & $\begin{array}{l}0.136 \\
(0.996)\end{array}$ & $\begin{array}{l}0.016 \\
(1.098)\end{array}$ & $\begin{array}{l}0.012 \\
(0.905)\end{array}$ \\
\hline $\log (1+$ County scientific value $)$ & & $\begin{array}{l}-0.018 \\
(-0.825)\end{array}$ & $\begin{array}{l}-0.005 \\
(-0.241)\end{array}$ & $\begin{array}{l}-0.001 \\
(-0.406)\end{array}$ & $\begin{array}{l}-0.000 \\
(-0.134)\end{array}$ \\
\hline $\log (1+$ County economic value $)$ & & $\begin{array}{l}0.112^{* * *} \\
(5.530)\end{array}$ & $\begin{array}{l}0.087^{* * *} \\
(4.435)\end{array}$ & $\begin{array}{l}0.009^{* * *} \\
(4.176)\end{array}$ & $\begin{array}{l}0.008^{* * *} \\
(4.282)\end{array}$ \\
\hline Log(County population) & & $\begin{array}{l}0.021 \\
(0.775)\end{array}$ & $\begin{array}{l}-0.059 \\
(-1.281)\end{array}$ & $\begin{array}{l}-0.006 \\
(-1.386)\end{array}$ & $\begin{array}{l}-0.006 \\
(-1.282)\end{array}$ \\
\hline Local firm & & $\begin{array}{l}0.691^{* *} \\
(1.990)\end{array}$ & $\begin{array}{l}0.736^{* *} \\
(2.149)\end{array}$ & $\begin{array}{l}0.076^{*} \\
(1.950)\end{array}$ & $\begin{array}{l}0.075^{* *} \\
(2.257)\end{array}$ \\
\hline Constant & Yes & No & No & No & No \\
\hline County fixed effects & No & Yes & Yes & Yes & Yes \\
\hline Firm $x$ date fixed effects & No & No & Yes & Yes & Yes \\
\hline$N$ & $4,470,927$ & $4,470,927$ & $4,470,927$ & $4,470,927$ & $4,470,927$ \\
\hline Adjusted $\mathrm{R}^{2}$ & 0.002 & 0.016 & 0.037 & 0.043 & 0.036 \\
\hline
\end{tabular}

Standard errors are clustered by county. T-statistics are in parentheses. $*, * *$, and $* * *$ represent significance at the $10 \%, 5 \%$, and $1 \%$ levels, respectively. Please refer to Appendix A for descriptions of all variables 


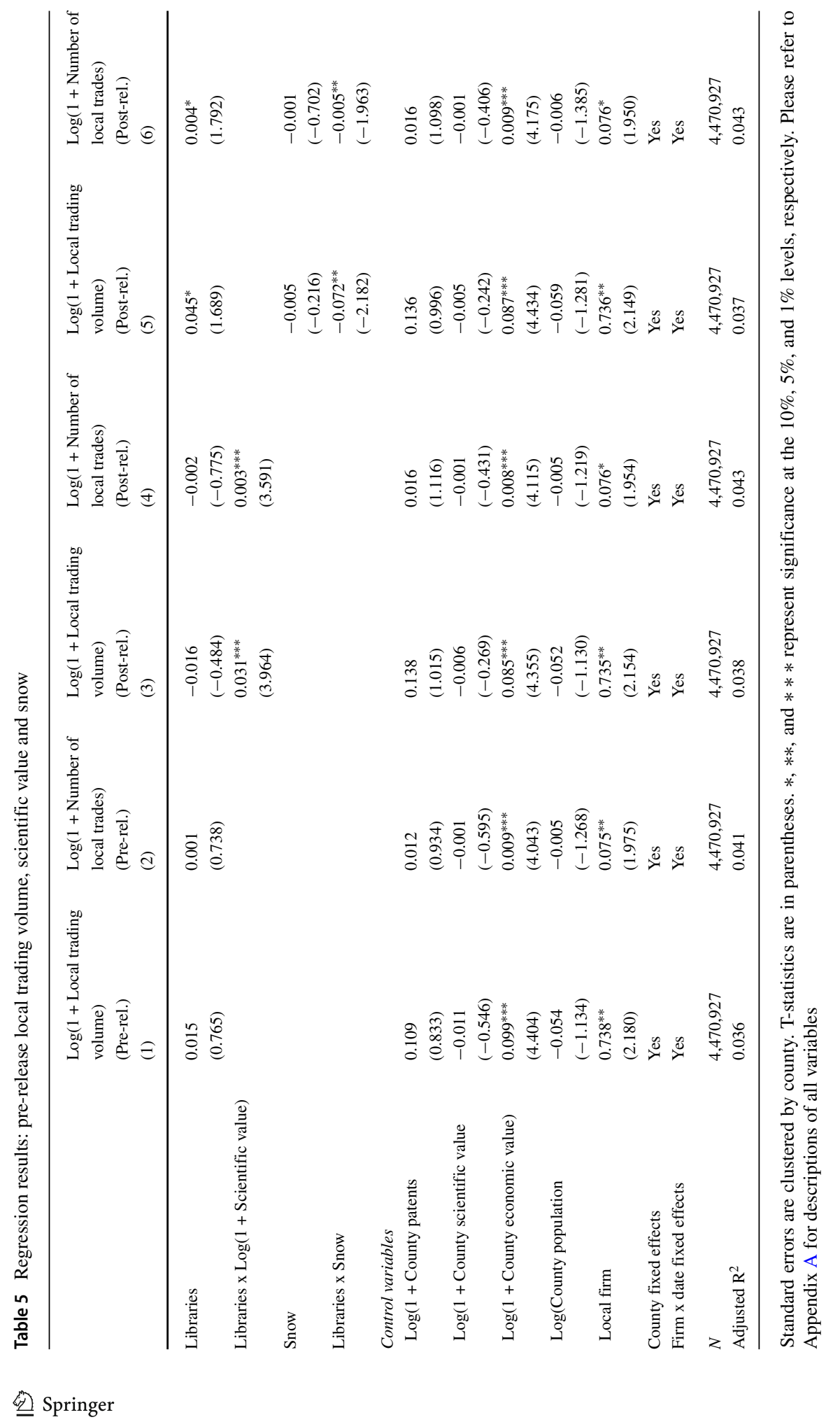




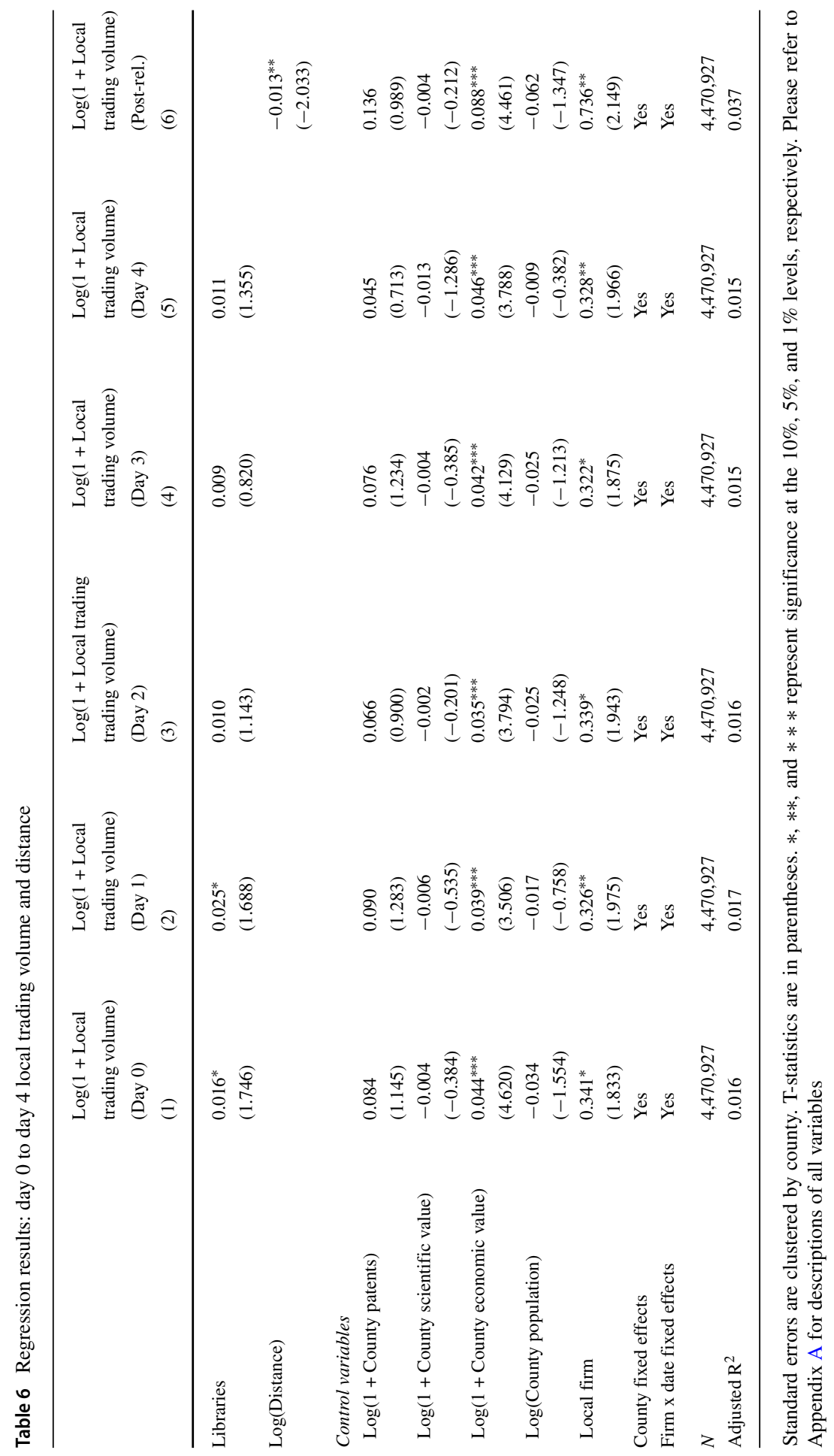




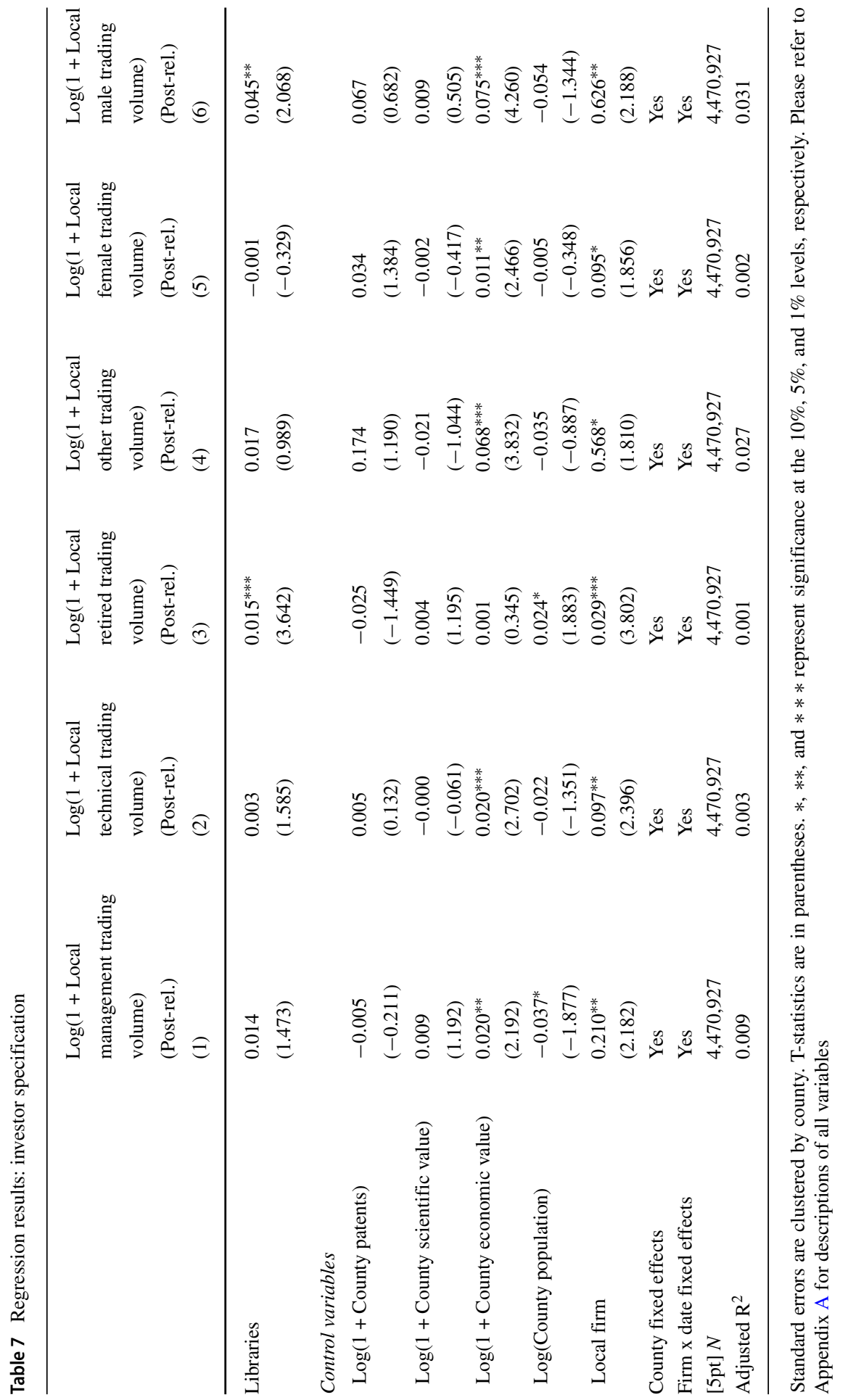


Table 8 Regression results: firm and event characteristics

\begin{tabular}{|c|c|c|c|c|c|c|}
\hline & \multicolumn{6}{|c|}{$\begin{array}{l}\log (1+\text { Local trading volume }) \\
\text { (Post-release) }\end{array}$} \\
\hline & (1) & (2) & (3) & (4) & (5) & (6) \\
\hline Libraries & $\begin{array}{l}-0.027 \\
(-0.817)\end{array}$ & $\begin{array}{l}0.029 \\
(1.087)\end{array}$ & $\begin{array}{l}0.025 \\
(0.882)\end{array}$ & $\begin{array}{l}0.049^{*} \\
(1.817)\end{array}$ & $\begin{array}{l}0.536^{* * *} \\
(2.710)\end{array}$ & $\begin{array}{l}0.044 \\
(1.638)\end{array}$ \\
\hline Libraries $x \log (1+$ Analyst following $)$ & $\begin{array}{l}0.045^{* * *} \\
(4.268)\end{array}$ & & & & & \\
\hline Libraries x Institutional ownership & & $\begin{array}{l}0.046^{* * *} \\
(3.654)\end{array}$ & & & & \\
\hline Libraries x Turnover & & & $\begin{array}{l}3.492^{* *} \\
(2.477)\end{array}$ & & & \\
\hline Libraries x Bid-ask spread & & & & $\begin{array}{l}-0.451^{* *} \\
(-2.144)\end{array}$ & & \\
\hline Libraries x Log(Daily patents) & & & & & $\begin{array}{l}-0.065^{* *} \\
(-2.411)\end{array}$ & \\
\hline Libraries x M\&A news & & & & & & $\begin{array}{l}0.120^{* * *} \\
(3.436)\end{array}$ \\
\hline \multicolumn{7}{|l|}{ Control variables } \\
\hline $\log (1+$ County patents $)$ & $\begin{array}{l}0.139 \\
(1.021)\end{array}$ & $\begin{array}{l}0.137 \\
(1.006)\end{array}$ & $\begin{array}{l}0.140 \\
(1.041)\end{array}$ & $\begin{array}{l}0.137 \\
(0.998)\end{array}$ & $\begin{array}{l}0.135 \\
(0.973)\end{array}$ & $\begin{array}{l}0.137 \\
(0.999)\end{array}$ \\
\hline $\log (1+$ County scientific value $)$ & $\begin{array}{l}-0.006 \\
(-0.278)\end{array}$ & $\begin{array}{l}-0.005 \\
(-0.256)\end{array}$ & $\begin{array}{l}-0.006 \\
(-0.306)\end{array}$ & $\begin{array}{l}-0.005 \\
(-0.243)\end{array}$ & $\begin{array}{l}-0.004 \\
(-0.214)\end{array}$ & $\begin{array}{l}-0.005 \\
(-0.244)\end{array}$ \\
\hline $\log (1+$ County economic value $)$ & $\begin{array}{l}0.086^{* * *} \\
(4.357)\end{array}$ & $\begin{array}{l}0.087^{* * *} \\
(4.404)\end{array}$ & $\begin{array}{l}0.084^{* * *} \\
(4.339)\end{array}$ & $\begin{array}{l}0.087^{* * *} \\
(4.433)\end{array}$ & $\begin{array}{l}0.089^{* * *} \\
(4.481)\end{array}$ & $\begin{array}{l}0.087^{* * *} \\
(4.422)\end{array}$ \\
\hline $\log ($ County population $)$ & $\begin{array}{l}-0.052 \\
(-1.130)\end{array}$ & $\begin{array}{l}-0.057 \\
(-1.244)\end{array}$ & $\begin{array}{l}-0.052 \\
(-1.121)\end{array}$ & $\begin{array}{l}-0.059 \\
(-1.276)\end{array}$ & $\begin{array}{l}-0.065 \\
(-1.389)\end{array}$ & $\begin{array}{l}-0.058 \\
(-1.266)\end{array}$ \\
\hline Local firm & $\begin{array}{l}0.733^{* *} \\
(2.143)\end{array}$ & $\begin{array}{l}0.735^{* *} \\
(2.148)\end{array}$ & $\begin{array}{l}0.735^{* *} \\
(2.162)\end{array}$ & $\begin{array}{l}0.736^{* *} \\
(2.148)\end{array}$ & $\begin{array}{l}0.736^{* *} \\
(2.148)\end{array}$ & $\begin{array}{l}0.735^{* *} \\
(2.148)\end{array}$ \\
\hline County fixed effects & Yes & Yes & Yes & Yes & Yes & Yes \\
\hline Firm $x$ date fixed effects & Yes & Yes & Yes & Yes & Yes & Yes \\
\hline$N$ & $4,470,927$ & $4,470,927$ & $4,470,927$ & $4,470,927$ & $4,470,927$ & $4,470,927$ \\
\hline Adjusted $\mathrm{R}^{2}$ & 0.038 & 0.037 & 0.037 & 0.037 & 0.037 & 0.037 \\
\hline
\end{tabular}

Standard errors are clustered by county. T-statistics are in parentheses. $*, * *$, and $* * *$ represent significance at the $10 \%, 5 \%$, and $1 \%$ levels, respectively. Please refer to Appendix A for descriptions of all variables 
Table 9 Regression results: return specification

\begin{tabular}{|c|c|c|c|c|c|c|}
\hline & $\begin{array}{l}\text { CAR } \\
\text { (20 days) } \\
\text { (1) }\end{array}$ & $\begin{array}{l}\text { CAR } \\
\text { (60 days) } \\
\text { (2) }\end{array}$ & $\begin{array}{l}\text { CAR } \\
\text { ( } 240 \text { days) } \\
\text { (3) }\end{array}$ & $\begin{array}{l}\text { BHAR } \\
\text { (20 days) } \\
\text { (4) }\end{array}$ & $\begin{array}{l}\text { BHAR } \\
\text { (60 days) } \\
\text { (5) }\end{array}$ & $\begin{array}{l}\text { BHAR } \\
\text { ( } 240 \text { days) } \\
\text { (6) }\end{array}$ \\
\hline Libraries & $\begin{array}{l}0.008^{* *} \\
(2.164)\end{array}$ & $\begin{array}{l}0.032^{* * *} \\
(6.059)\end{array}$ & $\begin{array}{l}0.049^{* * *} \\
(4.046)\end{array}$ & $\begin{array}{l}0.007^{* *} \\
(2.065)\end{array}$ & $\begin{array}{l}0.031^{* * *} \\
(5.372)\end{array}$ & $\begin{array}{l}0.079^{* * *} \\
(4.927)\end{array}$ \\
\hline \multicolumn{7}{|l|}{ Control variables } \\
\hline $\log (1+$ County patents $)$ & $\begin{array}{l}-0.003 \\
(-0.277)\end{array}$ & $\begin{array}{l}-0.042^{* *} \\
(-1.980)\end{array}$ & $\begin{array}{l}-0.096 \\
(-1.007)\end{array}$ & $\begin{array}{l}-0.003 \\
(-0.213)\end{array}$ & $\begin{array}{l}-0.050^{* *} \\
(-2.254)\end{array}$ & $\begin{array}{l}-0.082 \\
(-0.792)\end{array}$ \\
\hline $\log (1+$ County scientific value $)$ & $\begin{array}{l}0.010 \\
(1.439)\end{array}$ & $\begin{array}{l}0.017 \\
(1.105)\end{array}$ & $\begin{array}{l}0.039 \\
(0.692)\end{array}$ & $\begin{array}{l}0.010 \\
(1.449)\end{array}$ & $\begin{array}{l}0.017 \\
(1.185)\end{array}$ & $\begin{array}{l}0.060 \\
(0.905)\end{array}$ \\
\hline $\log (1+$ County economic value $)$ & $\begin{array}{l}-0.005 \\
(-0.736)\end{array}$ & $\begin{array}{l}0.001 \\
(0.043)\end{array}$ & $\begin{array}{l}-0.004 \\
(-0.089)\end{array}$ & $\begin{array}{l}-0.005 \\
(-0.797)\end{array}$ & $\begin{array}{l}0.000 \\
(0.013)\end{array}$ & $\begin{array}{l}-0.025 \\
(-0.412)\end{array}$ \\
\hline Log(County population) & $\begin{array}{l}0.014 \\
(0.685)\end{array}$ & $\begin{array}{l}0.044 \\
(1.278)\end{array}$ & $\begin{array}{l}0.823^{* * *} \\
(7.730)\end{array}$ & $\begin{array}{l}0.007 \\
(0.326)\end{array}$ & $\begin{array}{l}0.026 \\
(0.673)\end{array}$ & $\begin{array}{l}0.994^{* * *} \\
(7.515)\end{array}$ \\
\hline County fixed effects & Yes & Yes & Yes & Yes & Yes & Yes \\
\hline$N$ & 35,512 & 35,512 & 35,512 & 35,512 & 35,512 & 35,512 \\
\hline Adjusted $\mathrm{R}^{2}$ & 0.002 & 0.001 & 0.016 & 0.002 & 0.001 & 0.016 \\
\hline
\end{tabular}

Standard errors are clustered by county. T-statistics are in parentheses. $*, * *$, and $* * *$ represent significance at the $10 \%, 5 \%$, and $1 \%$ levels, respectively. Please refer to Appendix A for descriptions of all variables

Acknowledgments This paper is based on his dissertation at the University of Mannheim. The author thanks the editor, the anonymous reviewer, Jannis Bischof, Mark Schankerman, Dimitris, Holger Daske, Eddy Cardinaels, Johannes Voget, Matthias Breuer, Thomas Bourveau, Peter Pope, Catherine Shakespeare, Thorsten Sellhorn, Beatriz Garcia Osma, Dietmar Harhoff, William Rees, Andrew Toole, Christoph Sextroh, Stephan Hollander, Maria Correia, Philip Joos, Robin Litjens, Ruidi Shang, Marco Horvath, Nicolas Boob, Francisco Urzua, Benedikt Vogt (discussant). The author also thanks seminar participants at Bocconi University, the 2017 EAA Doctoral Colloquium in Accounting, the 2017 EAYE Spring Meeting of Young Economists, the 2017 Tilburg Accounting Mini Conference, the 2018 EAA Annual Congress, and the 2018 European Meeting of the Econometric Society for helpful feedback and discussions. The author gratefully acknowledges research funding from the Landesgraduiertenförderung Baden-Württemberg and the Julius Paul Stiegler Memorial Foundation. The author thanks Terry Odean for providing the discount brokerage data. He thanks Noah Stoffman for providing data on the market valuation of patents. All errors are his own.

Funding Open access funding provided by Università Commerciale Luigi Bocconi within the CRUICARE Agreement.

Open Access This article is licensed under a Creative Commons Attribution 4.0 International License, which permits use, sharing, adaptation, distribution and reproduction in any medium or format, as long as you give appropriate credit to the original author(s) and the source, provide a link to the Creative Commons licence, and indicate if changes were made. The images or other third party material in this article are included in the article's Creative Commons licence, unless indicated otherwise in a credit line to the 
material. If material is not included in the article's Creative Commons licence and your intended use is not permitted by statutory regulation or exceeds the permitted use, you will need to obtain permission directly from the copyright holder. To view a copy of this licence, visit http://creativecommons.org/licenses/by/4.0/.

\section{References}

Agrawal, Ajay, Alberto Galasso, and Alexander Oettl. 2017. Roads and innovation. Review of Economics and Statistics 99: 417-434.

Ayers, Benjamin C., Oliver Z. Li, and P. E. Yeung. 2011. Investor trading and the post-earningsannouncement drift. The Accounting Review 86: 385-416.

Barber, Brad M., and Terrance Odean. 2000. Trading is hazardous to your wealth: The common stock investment performance of individual investors. Journal of Finance 55: 773-806.

Barber, Brad M., and Terrance Odean. 2001. Boys will be boys: Gender, overconfidence, and common stock investment. Quarterly Journal of Economics 116: 261-292.

Barber, Brad M., and Terrance Odean. 2002. Online investors: Do the slow die first? Review of Financial Studies 15: 455-488.

Barber, Brad M., and Terrance Odean. 2008. All that glitters: The effect of attention and news on the buying behavior of individual and institutional investors. Review of Financial Studies 21: 785-818.

Belenzon, Sharon, and Mark Schankerman. 2013. Spreading the word: Geography, policy, and knowledge spillovers. Review of Economics and Statistics 95: 884-903.

Bhushan, Ravi. 1989. Collection of information about publicly traded firms: Theory and evidence. Journal of Accounting and Economics 11: 183-206.

Blankespoor, Elizabeth, Ed deHaan, John Wertz, and Christina Zhu. 2019. Why do individual investors disregard accounting information? The roles of information awareness and acquisition costs. Journal of Accounting Research 57: 53-84.

Bloomfield, Robert. 2002. The "incomplete revelation hypothesis" and financial reporting. Accounting Horizons 16: 233-243.

Brown, William H., and James A. Arshem. 1993. Survey of patent and trademark depository libraries 1991/1992, U.S. Patent and Trademark Office Report.

Bushee, Brian J., and Christopher F. Noe. 2000. Corporate disclosure practices, institutional investors, and stock return volatility. Journal of Accounting Research 38: 171-202.

Chapman, Kimball L., Nayana Reiter, Hal. D. White, and Christopher D. Williams. 2019. Information overload and disclosure smoothing. Review of Accounting Studies 24: 1486-1522.

Christensen, Hans B., Eric Floyd, Lisa Yao Liu, and Mark Maffett. 2017. The real effects of mandated information on social responsibility in financial reports: Evidence from mine-safety records. Journal of Accounting and Economics 64: 284-304.

Corwin, Shane A., and Paul Schultz. 2012. A simple way to estimate bid-ask spreads from daily high and low prices. Journal of Finance 67: 719-760.

Engelberg, Joseph E., and Christopher A. Parsons. 2011. The causal impact of media in financial markets. Journal of Finance 66: 67-97.

EY. 2014. Disclosure effectiveness companies embrace the call to action.

Fitzgerald, Tristan, Benjamin Balsmeier, Lee Fleming, and Gustavo Manso. 2019. Innovation search strategy and predictable returns. Management Science, Forthcoming.

Forbes. 2019. The greatest investor you've never heard of: An optometrist who beat the odds to become a billionaire.

Furman, Jeffrey L., Markus Nagler, and Martin Watzinger. 2020. Disclosure and subsequent innovation: Evidence from the patent depository library program, American Economic Review: Economic Policy, Forthcoming.

Glaeser, Stephen. 2018. The effects of proprietary information on corporate disclosure and transparency: Evidence from trade secrets. Journal of Accounting and Economics 66: 163-193.

Glaeser, Stephen, and Wayne R. Landsman. 2020, Deterrent disclosure. The Accounting Review, Forthcoming.

Glaeser, Stephen, Jeremy Michels, and Robert E. Verrecchia. 2020. Discretionary disclosure and manager horizon: Evidence from patenting. Review of Accounting Studies 25: 597-635. 
Graham, Stuart, and Deepak Hegde. 2015. Disclosing patents' secrets. Science 347: 236-237.

Hall, Bronwyn H., Adam B. Jaffe, and Manuel Trajtenberg. 2001. The nber patent citation data file: Lessons, insights and methodological tools, National Bureau of Economic Research Report.

Hegde, Deepak, Baruch Lev, and Chenqi Zhu. 2018. Patent disclosure and price discovery. Working Paper.

Hirschey, Mark, and Vernon J. Richardson. 2004. Are scientific indicators of patent quality useful to investors? Journal of Empirical Finance 11: 91-107.

Hirshleifer, David, Po-Hsuan Hsu, and Dongmei Li. 2013. Innovative efficiency and stock returns. Journal of Financial Economics 107: 632-654.

Hirshleifer, David, Po-Hsuan Hsu, and Dongmei Li. 2018. Innovative originality, profitability, and stock returns. Review of Financial Studies 31: 2553-2605.

Hirshleifer, David A., and Siew H. Teoh. 2003. Limited attention, information disclosure, and financial reporting. Journal of Accounting and Economics 36: 337-386.

Hochberg, Yael V., Carlos J. Serrano, and Rosemarie H. Ziedonis. 2018. Patent collateral, investor commitment, and the market for venture lending. Journal of Financial Economics 130: 74-94.

Hong, Harrison, Jeffrey D. Kubik, and Jeremy C. Stein. 2005. Thy neighbor's portfolio: Word-of-mouth effects in the holdings and trades of money managers. Journal of Finance 60: 2801-2824.

Huberman, Gur, and Tomer Regev. 2001. Contagious speculation and a cure for cancer: A nonevent that made stock prices soar. Journal of Finance 56: 387-396.

Ivković, Zoran, and Scott Weisbenner. 2005. Local does as local is: Information content of the geography of individual investors' common stock investments. Journal of Finance 60: 267-306.

Ivković, Zoran, and Scott Weisbenner. 2007. Information diffusion effects in individual investors' common stock purchases: Covet thy neighbors' investment choices. Review of Financial Studies 20: 13271357.

Jaffe, Adam B., Manuel Trajtenberg, and Rebecca Henderson. 1993. Geographic localization of knowledge spillovers as evidenced by patent citations. Quarterly Journal of Economics 108: 577-598.

Kim, Jinhwan, and Kristen Valentine. 2020. The innovation consequences of mandatory patent disclosures. Journal of Accounting and Economics, Forthcoming.

Kogan, Leonid, Dimitris Papanikolaou, Amit Seru, and Noah Stoffman. 2017. Technological innovation, resource allocation, and growth. Quarterly Journal of Economics 132: 665-712.

Leuz, Christian, and Peter D. Wysocki. 2016. The economics of disclosure and financial reporting regulation: Evidence and suggestions for future research. Journal of Accounting Research 54: 525-622.

Mann, William. 2018. Creditor rights and innovation: Evidence from patent collateral. Journal of Financial Economics 130: 25-47.

Martens, Tim, and Christoph J Sextroh. 2021. Analyst coverage overlaps and interfirm information spillovers. Journal of Accounting Research, Forthcoming.

Merton, Robert C. 1987. A simple model of capital market equilibrium with incomplete information. Journal of Finance 42: 483-510.

Oliver, Jeanne. 2002. Celebrating 25 years of libraries and uspto cooperation, U.S. Patent and Trademark Office Report.

Petersen, Mitchell A. 2009. Estimating standard errors in finance panel data sets: Comparing approaches. Review of Financial Studies 22: 435-480.

Saidi, Farzad, and Alminas Žaldokas. 2020. How does firms' innovation disclosure affect their banking relationships? Management Science, Forthcoming.

Seasholes, Mark S., and Ning Zhu. 2010. Individual investors and local bias. Journal of Finance 65: 1987-2010.

Shiller, Robert J., and John Pound. 1989. Survey evidence on diffusion of interest and information among investors. Journal of Economic Behavior \& Organization 12: 47-66.

Shores, David. 1990. The association between interim information and security returns surrounding earnings announcements. Journal of Accounting Research 28: 164-181.

Sneed, Martha C. 2000. Fully disclosed yet merely descriptive: Intricacies of training the patent and trademark information professional. Journal of Library Administration 29: 59-78.

USPTO. 2003. Patent and trademark depository library program 2002 customer satisfaction survey, U.S. Patent and Trademark Office Report.

Publisher's note Springer Nature remains neutral with regard to jurisdictional claims in published maps and institutional affiliations. 